\title{
FERTILITAS MIGRAN DAN FAKTOR YANG MEMENGARUHI FERTILITAS DI JAWA BARAT
}

\author{
Rindang Ekawati ${ }^{1}$, Rina Herartri ${ }^{2}$, Nuraini ${ }^{3}$, Laili Rahayuwati ${ }^{4}$, dan Sukamdi ${ }^{5}$ \\ ${ }^{1}$ Bidang Pelatihan dan Pengembangan-Perwakilan BKKBN Provinsi Jawa Barat, ${ }^{2}$ Pusat \\ Penelitian Kependudukan - BKKBN Pusat, Jakarta, ${ }^{3}$ Statistisi-Perwakilan BKKBN Provinsi \\ Jawa Barat, ${ }^{4}$ Fakultas Keperawatan, Universitas Padjadjaran, Bandung, ${ }^{5}$ Fakultas Geografi, \\ Universitas Gadjah Mada, Yogyakarta
}

Korespondensi: Laili Rahayuwati (e-mail: laili.rahayuwati@unpad.ac.id)

\begin{abstract}
Abstrak
Migrasi merupakan salah satu faktor yang memengaruhi dinamika penduduk, baik melalui jumlah migran maupun fertilitas migran. Jumlah migrasi yang besar ke Provinsi Jawa Barat merupakan salah satu penyebab peningkatan jumlah penduduk yang cukup besar. Jika migran memiliki fertilitas yang lebih tinggi dibandingkan dengan nonmigran, maka pengaruh tersebut akan lebih besar lagi. Penelitian ini bertujuan untuk mengkaji perbedaan fertilitas antara migran dan nonmigran serta faktor-faktor yang memengaruhi fertilitas di Jawa Barat. Data yang digunakan adalah data Survei Sosial Ekonomi Nasional (Susenas) tahun 2015. Analisis dilakukan menggunakan statistik deskriptif dan inferensial. Hasil penelitian menunjukkan terdapat kecenderungan migran memiliki fertilitas yang lebih tinggi dibandingkan dengan nonmigran. Sementara itu, faktor sosial ekonomi yang berpengaruh terhadap fertilitas adalah pendidikan, usia kawin pertama, penggunaan alat kontrasepsi, dan kegiatan utama (pekerjaan).
\end{abstract}

Kata kunci: fertilitas, migrasi, faktor sosial ekonomi

\section{THE FERTILITY OF MIGRANTS AND FACTORS AFFECTING FERTILITY IN WEST JAVA PROVINCE}

\begin{abstract}
Migration is one of the factors that influences the dynamics of population, both through the number of migrants and the fertility of migrants. The large number of migrants to West Java Province is one of the causes of a considerable increase in population. If migrants have higher fertility than non-migrants, the effect will be even greater. This study aims to examine the difference of fertility between migrants and non-migrants as well as factors affecting fertility in West Java. The data used is 2015 National Socio-Economic Survey (Susenas). The analysis is done using descriptive and inferential statistics. The results show that there is a tendency for migrants to have higher fertility compared with non-migrants while the socio-economic factors that have an effect on fertility are education, first marriage age, use of contraceptives, and main activities (work).
\end{abstract}

Keywords: fertility, migration, socio-economic factors 


\section{Pendahuluan}

Berdasarkan hasil Sensus Penduduk tahun 2000 dan 2010, dapat diketahui bahwa jumlah migran seumur hidup bersih (neto) di Jawa Barat dari tahun 2000 ke tahun 2010 meningkat drastis dari 1.225.603 jiwa menjadi 2.710.927 jiwa atau meningkat sebesar 121,19 persen. Dibandingkan dengan provinsi lainnya di Pulau jawa, Provinsi Jawa Barat merupakan salah satu provinsi yang memiliki migrasi bersih positif. Peningkatan migrasi di Jawa Barat tidak lepas dari peran daerah ini sebagai buffer zone bagi Jakarta. Kenaikan jumlah migran tersebut berpengaruh terhadap peningkatan jumlah penduduk di Jawa Barat dari 43.053.732 jiwa tahun 2000 menjadi 7.330.259 jiwa tahun 2010 .

Migrasi yang tinggi merupakan suatu tantangan sekaligus ancaman bagi perkembangan suatu daerah. Dikatakan tantangan karena migrasi berkontribusi terhadap pembangunan di daerah tujuan. Namun, migrasi akan menjadi ancaman jika tidak terjadi integrasi antara migran dan nonmigran sehingga mengganggu social cohesion dan berpotensi menimbulkan konflik. Di luar kedua hal tersebut, dari sisi demografi, migrasi akan berkontribusi positif maupun negatif terhadap angka kelahiran di daerah tujuan.

Dalam konteks perubahan angka fertilitas, migrasi di Jawa Barat kemungkinan berkontribusi terhadap penurunan TFR (Total Fertility Rate) yang lambat pada kurun waktu sepuluh tahun terakhir (SDKI 2002/2003 sampai dengan SDKI 2012). Hasil SDKI (Survei Demografi dan Kesehatan) tahun 2002/2003. menunjukkan bahwa TFR di Jawa Barat adalah 2,6; sedangkan SDKI tahun 2012 mencatat TFR sebesar 2,5 anak. Data tersebut menunjukkan terdapat sedikit penurunan dalam periode sepuluh tahun.
Secara teoretis, hubungan antara migrasi dan fertilitas dapat dijelaskan dengan beberapa hipotesis (Kulu, 2003). Pertama adalah socialization hypothesis yang mendasarkan pada premis bahwa perilaku fertilitas migran merefleksikan preferensi fertilitas yang dominan selama masa anakanak. Oleh karena itu, migran menunjukkan tingkat fertilitas yang serupa dengan penduduk di daerah asal dan konvergensi terhadap tingkat fertilitas penduduk di daerah tujuan hanya terjadi pada generasi berikutnya (mengingat adanya perbedaan antargenerasi). Kedua adalah adaptation hypothesis yang menyebutkan bahwa perilaku fertilitas migran, cepat atau lambat, mendekati perilaku dominan di daerah tujuan. Ketiga adalah selection hypothesis, yaitu migran adalah kelompok orang tertentu yang preferensi fertilitasnya lebih mirip dengan orang-orang yang berada di tempat tujuan daripada di tempat asal. Keempat adalah disruption hypothesis yang menjelaskan bahwa segera setelah migrasi, migran menunjukkan tingkat fertilitas yang rendah karena adanya faktor-faktor pengganggu yang terkait dengan proses migrasi.

Teori klasik yang digunakan untuk menganalisis hubungan antara faktor sosial ekonomi dan fertilitas adalah teori dari Davis dan Blake (1956). Teori tersebut menjelaskan bahwa pengaruh faktor sosial ekonomi terhadap fertilitas harus melalui variabel antara (intermediate variable). Variabel antara tersebut terdiri atas sebelas variabel, tetapi pada umumnya yang paling sering digunakan dalam penelitian adalah penggunaan kontrasepsi dan usia kawin pertama yang disebabkan oleh keterbatasan data.

Beberapa hasil penelitian menunjukkan bahwa fertilitas migran cenderung lebih tinggi dibandingkan dengan nonmigran. Penelitian di Bali oleh Sudibya, dkk. (2013) 
menunjukkan bahwa fertilitas migran adalah 2,5 dibandingkan dengan nonmigran yang sebesar 2,32. Penelitian lain di Kota Singaraja, Provinsi Bali, oleh Haribaik, dkk. (2017) juga menghasilkan kesimpulan yang sama, yaitu paritas migran lebih besar (3-4 anak) dibandingkan dengan nonmigran (1-2 anak). Hasil yang senada lainnya menyebutkan bahwa migran cenderung memiliki anak yang lebih besar dibandingkan dengan nonmigran dan hal itu juga ditemukan di Jakarta (download.portalgaruda.org/ article.php?article=351415\&val). Penelitian lain di Daerah Istimewa Yogyakarta yang dilakukan oleh Alfana dan Gyarsih (2015) juga menunjukkan hasil yang sama.

Berdasarkan beberapa hasil penelitan tersebut, maka dapat diduga bahwa kontribusi migrasi terhadap dinamika penduduk bukan hanya karena jumlah migrannya, tetapi juga fertilitas migran ikut berpengaruh. Pertanyannya adalah apakah hubungan status migran dan fertilitas di Jawa Barat juga sama dengan hasil penelitian di daerah yang lain? Kontribusi migrasi terhadap fertilitas di suatu wilayah merupakan isu menarik dalam membahas dinamika penduduk di suatu wilayah. Hal itu karena penjelasan terhadap perbedaan fertilitas antara migran dan migran akan menjelaskan faktor yang berkontribusi terhadap perubahan jumlah, distribusi, dan komposisi penduduk di suatu wilayah. Isu tersebut menarik untuk dikaji di Jawa Barat, sebab provinsi ini merupakan salah satu provinsi yang memiliki angka migrasi paling besar dan bersifat dinamis.

Studi ini merupakan studi lanjutan yang dilakukan oleh Herartri, dkk. tahun 2015 yang berjudul "Perbedaan Fertilitas Migran dan Nonmigran di Provinsi Jawa Barat" dan menggunakan data Susenas 2012. Dalam penelitian tersebut, konsep migrasi yang digunakan adalah migrasi total. Migrasi total adalah migrasi yang diukur berdasarkan tempat tinggal yang saat survei dilakukan berbeda dengan tempat tinggal sebelumnya, tanpa mempertimbangkan waktu pindahnya. Kelemahan pada studi ini terletak pada konsep migrasi. Karena menggunakan konsep migrasi total, maka hasilnya tidak dapat menunjukkan kondisi paling akhir atau terkini.

Memperhatikan kelemahan tersebut, maka dalam studi ini, konsep migrasi yang digunakan adalah migrasi risen, yaitu migrasi yang didasarkan pada status tempat tinggal sekarang (saat survei dilakukan) dibandingkan dengan tempat tinggal lima tahun yang lalu. Di samping itu, studi ini juga memiliki kelebihan karena menggunakan data Susenas terbaru, yaitu tahun 2015 .

\section{Metode Penelitian}

Studi ini menggunakan pendekatan kuantitatif, yaitu analisis data sekunder, sedangkan sumber data yang digunakan adalah Susenas tahun 2015. Unit analisis yang digunakan adalah wanita pernah kawin berusia 15-49 tahun, yaitu anggota rumah tangga wanita yang saat survei dilakukan berstatus kawin, cerai hidup, atau cerai mati dan berumur15-49 tahun yang menjadi sampel Susenas 2015.

Dari jumlah wanita pernah kawin (WPK) yang berjumlah 15.950 dan berumur 15-49 tahun di Jawa Barat, sebanyak 269 orang (1,72 persen) merupakan penduduk migran risen masuk. Kemudian data diolah dan dianalisis menggunakan statistik deskriptif dan regresi logistik. Variabel-variabel yang digunakan dalam regresi logistik adalah sebagai berikut.

Y: Variabel dependen, jumlah anak lahir hidup merupakan variabel dummy dengan kode 1 jika jumlah anak lahir 
hidup yang dimiliki wanita migran $>2$ dan 0 jika jumlah anak lahir hidup yang dimiliki wanita migran $\leq 2$

Xi: Variabel Independen (penjelas), yang terdiri atas

a. daerah tempat tinggal, kode 1 jika bertempat tinggal di perkotaan dan 0 jika bertempat tinggal di perdesaan

b. pendidikan, kode 1 jika pendidikan yang ditamatkan >SMA dan 0 jika pendidikan yang ditamatkan $\leq$ SMA

c. usia kawin pertama, kode 1 jika usia kawin pertama $<21$ tahun dan 0 jika usia kawin pertama $\geq 21$ tahun

d. status migran, kode 1 jika berstatus migran risen dan 0 berstatus nonmigran

e. penggunaan kontrasepsi, kode 1 jika pernah dan sedang menggunakan kontrasepsi dan 0 jika tidak pernah menggunakan kontrasepsi

f. pekerjaan, kode 1 jika bekerja dan 0 jika tidak bekerja

g. umur sebagai variabel rasio.

\section{Hasil dan Pembahasan}

Karakteristik Wanita Pernah Kawin 15-49 tahun

Gambaran umum tentang wanita pernah kawin (WPK) umur 15-49 tahun dengan pengelompokan migran risen dan nonmigran risen dapat dilihat pada Tabel 1. Distribusi WPK menurut kelompok umur memperlihatkan pola yang sama antara migran dan nonmigran. Pola distribusi umur WPK migran menurut kelompok umur menunjukkan pola huruf $U$ terbalik dengan puncaknya pada umur 25-39 tahun (65 persen). Pola yang sama ditemukan pada kelompok nonmigran meskipun jumah pada kelompok umur puncak (25-39) lebih rendah dibandingkan dengan kelompok migran, yaitu 52 persen. Hal inilah yang menyebabkan median umur untuk kelompok migran lebih muda dibandingkan dengan nonmigran (Tabel 1).

Tabel 1 Persentase Nonmigran dan Migran Risen Wanita Pernah Kawin 15-49 Tahun per Kelompok Umur di Jawa Barat

\begin{tabular}{lccccc}
\hline \multirow{2}{*}{$\begin{array}{c}\text { Kelompok } \\
\text { umur }\end{array}$} & \multicolumn{5}{c}{ Wanita Pernah Kawin 15-49 tahun } \\
\cline { 2 - 5 } & nonmigran risen & $\%$ & migran risen & $\%$ & Total \\
\hline $15-19$ & 314 & 2,00 & 4 & 1,49 & 318 \\
$20-24$ & 1.279 & 8,16 & 30 & 11,15 & 1.309 \\
$25-29$ & 2.008 & 12,81 & 62 & 23,05 & 2.070 \\
$30-34$ & 3.029 & 19,32 & 52 & 19,33 & 3.081 \\
$35-39$ & 3.147 & 20,07 & 62 & 23,05 & 3.209 \\
$40-44$ & 3.187 & 20,32 & 41 & 15,24 & 3.228 \\
$45-49$ & 2.717 & 17,33 & 18 & 6,69 & 2.735 \\
Total & 15.681 & 100 & 269 & 100 & 15.950 \\
\hline Mean & 35.93 & \multicolumn{5}{c}{33.29} \\
\hline Median & 36.00 & 33.00 & \\
\hline
\end{tabular}

Sumber: Susenas, 2015 (diolah) 
Sebagaimana telah dijelaskan pada di kabupaten dan kota yang terdekat dengan bagian sebelumnya, Provinsi Jawa Barat DKI Jakarta, yaitu Kabupaten Bogor, Kota merupakan buffer zone bagi Jakarta. Data Bogor, Kabupaten Bekasi, Kota Bekasi, dana Susenas 2015 menunjukkan bahwa daerah Kabupaten Kerawang. Keenam kabupaten/ asal migran adalah DKI Jakarta. Sementara itu, data migrasi risen hasil Sensus Penduduk 2010 maupun Supas (Survei Penduduk Antar Sensus) tahun 2015 menunjukkan bahwa migrasi risen DKI Jakarta adalah negatif. Hal itu berarti bahwa lebih banyak penduduk yang keluar dari Jakarta dibandingkan dengan yang masuk ke DKI Jakarta. Hasil Supas 2015 menunjukkan bahwa 62,28 persen penduduk dari DKI Jakarta menuju ke Jawa Barat.

Gambar 1 menunjukkan bahwa seperlima lebih migran risen di Provinsi Jawa Barat terkonsentrasi di Kota Depok. Selebihnya yang berjumlah 40,72 persen migran berada kota inilah bersama-sama dengan Kabupaten Tangerang dan Kota Tangerang merupakan daerah penyangga bagi DKI Jakarta. Sebagian besar penduduk yang bekerja di DKI Jakarta bertempat tinggal di kabupaten/ kota tersebut sebagai migran.

Hasil penelitian yang menunjukkan bahwa Kota Depok, Kabupaten dan Kota Bogor, serta Kabupaten dan Kota Bekasi adalah wilayah terdekat dari DKI Jakarta serta merupakan daerah asal terbesar WPK migran risen. Hal tersebut dapat dijelaskan secara teoretis pula. Berdasarkan Teori Selection menurut Caldwell (1982) (lihat juga Kulu, 2003;

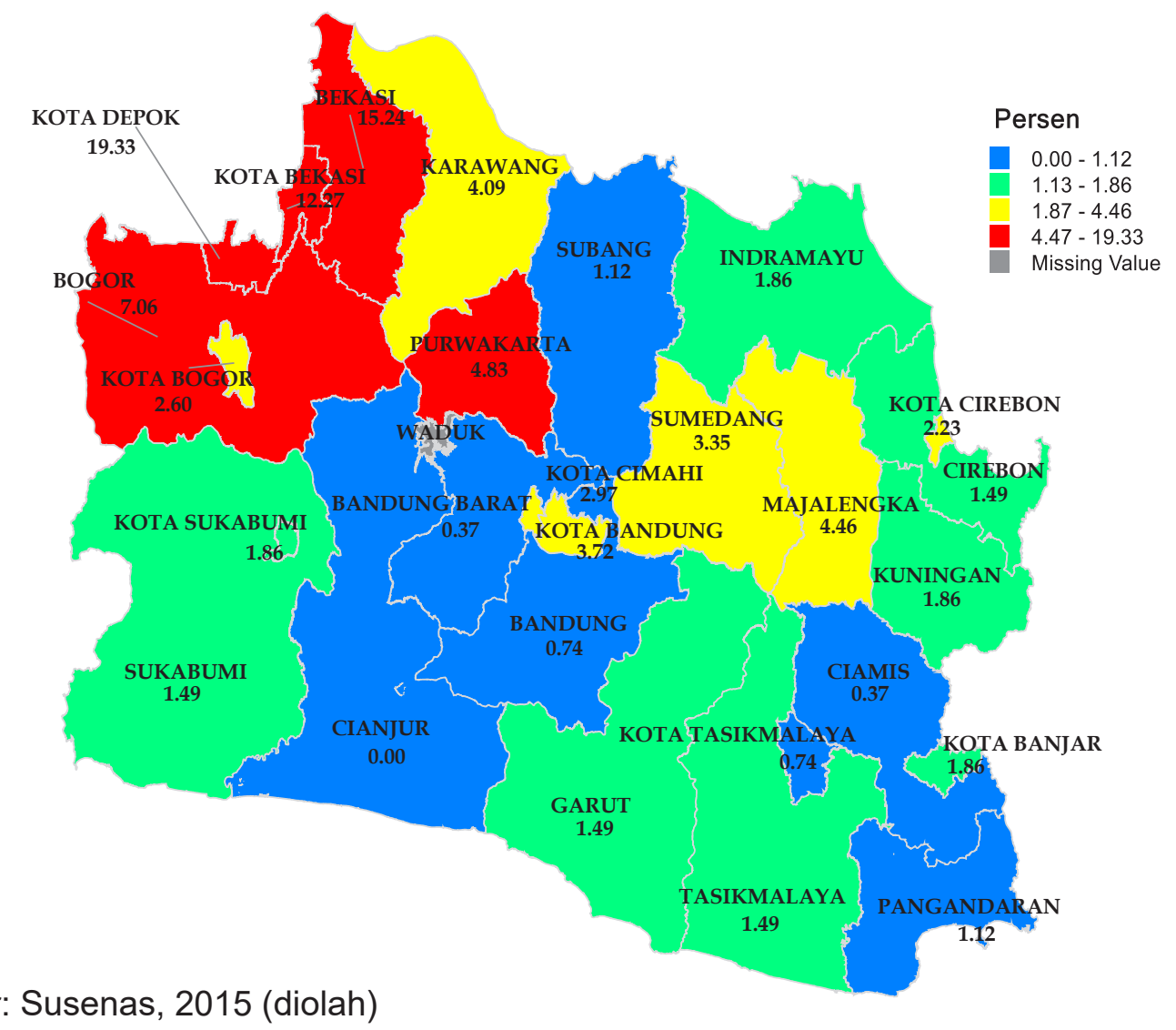

Sumber: Susenas, 2015 (diolah)

Gambar 1 Persentase Migran Risen Masuk (WPK 15-49 Tahun) menurut Kabupaten/Kota di Jawa Barat Berdasarkan Data Susenas 2015 
Hervitz, 1985; Ribe \& Schultz, 1980; Herartri, Rina, dkk. 2013), keluarga yang melakukan migrasi 'terseleksi' berdasarkan kesamaan karakteristik sosial ekonomi dengan penduduk di wilayah tujuan. Kedekatan wilayah memungkinkan terjadinya dan mempermudah migran berinteraksi dengan penduduk asal karena karakteristik sosial ekonomi yang mirip, atau bahkan sama.

Faktor pendorong yang diduga menjadi penyebab migran risen dari DKI Jakarta menuju ke kabupaten dan kota tujuan migran tersebut adalah makin mahalnya biaya hidup di daerah asal. Sebaliknya, terdapat beberapa faktor penarik yang ada di daerah tujuan selain biaya hidup yang lebih murah, yaitu. 1) Adanya harapan akan memperoleh kesempatan untuk memperbaikan taraf hidup, 2) kesempatan untuk memperoleh pendidikan yang lebih baik, serta 3) keadaan lingkungan dan keadaan hidup yang lebihnya aman dan menyenangkan, misalnya iklim, perumahan, sekolah, dan fasilitas-fasilitas publik lainnya.

Karakteristik lain memperlihatkan bahwa dari sisi ketenagakerjaan, kegiatan utamayang dilakukan oleh sebagian besar (43,36 persen) WPK migran adalah bekerja, sedangkan wanita nonmigran hanya 39,78 persen yang berstatus bekerja. Selain itu, sebanyak 20,56 persen wanita migran memiliki usaha sendiri dibandingkan dengan 14,16 persen wanita nonmigran yang memiliki usaha sendiri. Jika berusaha sendiri diklasifikasikan sebagai sektor informal, data tersebut menunjukkan bahwa wanita migran yang bekerja di sektor informal lebih besar dibandingkan dengan wanita nonmigran. Sementara itu, sektor jasa yang terdiri atas perdagangan, hotel, dan rumah makan merupakan sektor yang menjadi gantungan hidup para wanita, baik migran maupun nonmigran (35,40 persen). Besarnya wanita yang bekerja di sektor jasa ini sekaligus melengkapi informasi sebelumnya yang menyatakan bahwa migran cenderung bekerja di sektor informal karena secara umum, sektor jasa di Indonesia didominasi oleh sektor informal.

Data menarik lain menunjukkan bahwa 20,30 persen WPK bekerja di sektor industri pengolahan dan hanya sebagian kecil yang bekerja di sektor pertanian. Wanita migran yang bekerja di sektor pertanian sebanyak 17,80 persen, sedangkan wanita nonmigran hanya 9,73 persen. Data ini sekaligus memberikan gambaran yang cukup menarik, sebab wanita migran yang bekerja di sekor pertanian cukup besar, bahkan lebih besar dibandingkan dengan wanita nonmigran. Namun, penelitian ini tidak dapat menjelaskan secara mendalam alasan banyak perempuan migran bekerja di sektor pertanian. Untuk itu, diperlukan penelitian lanjutan yang akan melakukan analisis fenomena tersebut.

Selanjutnya salah satu variabel penting dalam analisis fertilitas adalah usia pernikahan. Data Susenas 2015 menunjukkan bahwa WPK migran memiliki usia pernikahan yang lebih tinggi dibandingkan dengan nonmigran. Sebanyak 37,93 persen wanita migran menikah pertama pada umur kurang dari 21 tahun, sedangkan wanita nonmigran yang menikah kurang dari 21 tahun jauh lebih besar, yaitu 64,38 persen.

Data fertilitas menunjukkan 85,13 persen wanita migran memiliki dua atau kurang anak lahir hidup, sedangkan wanita nonmigran hanya 67,64 persen. Hal ini merupakan indikasi bahwa fertilitas migran lebih rendah dibandingkan dengan nonmigran. Anehnya, data ini tidak paralel dengan penggunaan alat kontrasepsi. Jumlah wanita migran yang menggunakan alat kontrasepsi jauh lebih rendah (48,70 persen) dibandingkan dengan wanita nonmigran yang tercatat 60,02 persen. Akan tetapi, kondisi sebaliknya terlihat pada pemakaian alat kontrasepsi Metode 
Kontrasepsi Jangka Panjang (MKJP) yang meliputi alat kontrasepsi dalam rahim (IUD) dan implan. Kontrasepsi mantap pada wanita migran tercatat lebih tinggi, yaitu 28,24 persen, dibandingkan dengan wanita nonmigran yang hanya 18,67 persen.

Alasan tidak ber-KB karena takut efek samping diungkapkan oleh 9,67 persen migran dan 13,04 persen wanita nonmigran. Sementara itu, responden mengatakan tidak ber-KB karena alasan terganggunya fertilitas diungkapkan oleh 16,67 persen migran dan 26,37 persen oleh wanita nonmigran. Berkaitan dengan proses persalinan, untuk penolong persalinan anak terakhir, wanita migran yang persalinannya ditolong oleh dukun beranak/paraji sebesar 3,17 persen, sedangkan wanita nonmigran 9,06 persen.

Dilihat dari variabel sosial ekonomi, yaitu status pekerjaan, jenis usaha, lapangan usaha utama, umur kawin pertama kurang dari 21 tahun, jumlah anak lahir hidup kurang atau sama dengan dua anak, pemakaian alat dan obat kontrasepsi, alasan tidak ber-KB, dan penolong persalinan; pada umumnya WPK 15-49 tahun yang berstatus migran berada pada status yang lebih baik dibandingkan dengan WPK nonmigran. Melihat daerah asal terbesar migran risen adalah DKI Jakarta, yang merupakan ibu kota negara, besar kemungkinan kaum migran risen ini telah berada pada posisi yang lebih baik daripada penduduk nonmigran. Seperti pada variabel demografi umur kawin pertama di bawah 21 tahun, hal itu lebih banyak terjadi pada penduduk nonmigran. Umur kawin pertama Provinsi Jawa Barat menurut hasil SDKI 2012 masih berada di bawah 20 tahun. Demikian pula jika ditinjau dari penolong persalinan oleh dukun beranak/paraji, WPK migran yang sebagian besar berasal dari DKI Jakarta lebih mudah mengakses penolong persalinan dari tenaga medis di fasilitas kesehatan yang ada.
Fertilitas Migrandan Faktoryang Memengaruhi

Perlu dicatat bahwa dalam analisis regresi, yang digunakan sebagai variabel tergantung adalah rata-rata jumlah anak lahir hidup yang diukur dalam bentuk variabel dummy, yaitu kurang atau sama dengan dua dan lebih besar dari dua. Hal itu didasarkan pada asumsi bahwa jumlah anak dua merupakan benchmark untuk menjelaskan jumlah anak sedikit atau banyak. Wanita nonmigran (risen masuk) pernah kawin 15-49 tahun mempunyai 1,68 kali kemungkinan (odds) untuk mempunyai anak lebih dari dua $(>2)$ dibandingkan dengan wanita migran pernah kawin 15-49 tahun. Dengan kata lain, wanita migran (risen masuk) mempunyai 0,595 kali kemungkinan (odds) untuk mempunyai anak >2 dibandingkan dengan yang nonmigran (lihat Tabel 2).

Hasil ini sekaligus menegaskan hasil penelitian lain yang menunjukkan bahwa migran memiliki fertilitas yang lebih tinggi dibandingkan dengan nonmigran. Jika yang dgunakan adalah socialization hypothesis, maka fertilitas migran seharusnya merefleksikan fertilitas daerah asal. Dalam pembahasan sebelumnya disebutkan bahwa sebagian besar migran berasal dari DKI Jakarta yang notabene memiliki angka fertilitas yang lebih rendah. Hasil SDKI 2012 menunjukkan bahwa TFR di DKI Jakarta adalah 2,3; sedangkan di Jawa Barat adalah 2,5 . Tampaknya perbedaan ini terkait dengan kondisi sosial ekonomi.

Faktor apakah yang mampu menjelaskan perbedaan tersebut? Hasil analisis menunjukkan bahwa daerah tempat tinggal, pendidikan (dengan derajat kepercayaan 10 persen), usia kawin pertama, pekerjaan, dan pemakaian kontrasepsi berpengaruh secara signifikan terhadap fertilitas (jumlah anak lahir hidup) pada wanita pernah kawin 15-49 tahun (Tabel 2). 
Tabel 2 Koefisien Regresi Logistik

\begin{tabular}{lrrrrrr}
\hline & \multicolumn{1}{l}{ B } & \multicolumn{1}{c}{ S.E. } & \multicolumn{1}{c}{ Wald } & df & \multicolumn{1}{c}{ Sig. } & \multicolumn{1}{c}{ Exp(B) } \\
\hline Daerah(1) & .224 & .043 & 26.853 & 1 & .000 & 1.251 \\
Pendid(1) & -.135 & .081 & 2.749 & 1 & .097 & .874 \\
ukp(1) & .943 & .046 & 420.920 & 1 & .000 & 2.568 \\
migranrisen(1) & -.519 & .191 & 7.359 & 1 & .007 & .595 \\
Pkontrasepsi(1) & .786 & .049 & 260.580 & 1 & .000 & 2.195 \\
Pekerjaan(1) & -.247 & .040 & 37.613 & 1 & .000 & .781 \\
Umur & .156 & .003 & 2489.355 & 1 & 0.000 & 1.168 \\
Constant & -7.694 & .164 & 2188.595 & 1 & 0.000 & .000 \\
\hline
\end{tabular}

Sumber: Susenas, 2015 (diolah)

Tabel 2 juga menunjukkan beberapa isu yang menarik sebagai berikut.

1. Wanita pernah kawin 15-49 tahun yang tinggal di daerah perkotaan mempunyai 1,25 kali kemungkinan (odds) untuk mempunyai anak lebih lebih dari dua (> 2) dibandingkan dengan wanita pernah kawin 15-49 tahun yang tinggal di desa.

2. Wanita pernah kawin 15-49 tahun yang memiliki pendidikan setingkat SMA ke bawah ( $\leq$ SMA) mempunyai 1,144 kali kemungkinan (odds) untuk mempunyai anak lebih dari dua (>2) dibandingkan dengan wanita pernah kawin 15-19 tahun yang memiliki pendidikan di atas SMA (>SMA). Dapat dikatakan pula bahwa wanita yang pendidikan >SMA mempunyai 0,87 kali kemungkinan untuk mempunyai anak lebih dari dua $(>2)$ dibandingkan dengan wanita pernah kawin 15-19 tahun yang memiliki pendidikan di bawah atau setingkat SMA ( $S$ SMA).

3. Wanita pernah kawin 15-49 tahun yang usia kawin pertamanya di bawah umur 21 tahun (UKP <21) mempunyai 2,57 kali kemungkinan (odds) untuk mempunyai anak >2 dibandingkan dengan wanita pernah kawin 15-49 tahun yang usia kawin pertamanya berumur 21 tahun ke atas (UKP $\geq 21)$.

4. Wanita pernah kawin 15-49 tahun yang tidak bekerja mempunyai 1,28 kali kemungkinan (odds) untuk mempunyai anak lebih dari dua (>2) dibandingkan dengan wanita pernah kawin 15-49 tahun yang bekerja. Dengan kata lain, wanita bekerja mempunyai 0,78 kali kemungkinan (odds) untuk mempunyai anak $>2$ dibandingkan dengan yang tidak bekerja.

5. Wanita yang menggunakan kontrasepsi (pernah dan sedang) mempunyai 2,19 kali kemungkinan (odds) untuk mempunyai anak >2 dibandingkan dengan yang tidak pernah menggunakan kontrasepsi.

Hasil tersebut menunjukkan bahwa kemungkinan WPK mempunyai anak lebih besar daripada 2 adalah mereka yang bertempat tinggal di perkotaan, berpendidikan rendah, usia kawin kurang dai 21 tahun, dan tidak bekerja. Wanita nonmigran berpeluang lebih besar untuk memiliki anak lebih daripada dua orang dibandingkan dengan 
WPK migran. Keadaan ini sesuai dengan teori yang menjelaskan perbedaan pola fertilitas di antara migran dan nonmigran, yaitu socialization. Teori itu menyatakan bahwa keputusan mengenai fertilitas dipengaruhi oleh lingkungan keluarga pada masa kecil (di daerah asal) (Caldwell, 1982; Kulu, 2003; Hervitz, 1985; Ribe \& Schultz, 1980; Herartri, Rina, dkk., 2013).

Wanita pernah kawin 15-49 tahun yang bertempat tinggal di perkotaan berpeluang memiliki anak lebih daripada dua anak dibandingkan dengan mereka yang tinggal di daerah perdesaan. Hal ini sesuai dengan hasil SDKI 2007 dan SDKI 2012 Provinsi Jawa Barat yang menyatakan bahwa tingkat angka fertilitas total (TFR) di wilayah perkotaan lebih besar dibandingkan dengan wilayah perdesaan.

WPK 15-49 tahun yang berpendidikan SLTA ke bawah, umur kawin pertama kurang dari 21 tahun, dan tidak bekerja berpeluang memiliki anak lebih daripada dua anak. Hal ini dapat dijelaskan bahwa wanita yang berpendidikan lebih rendah cenderung tidak memiliki pekerjaan dan menikah pada usia yang lebih muda.

Hal yang aneh adalah hasil yang menunjukkan bahwa WPKyang menggunakan alat kontrasepsi memiliki kemungkinan lebih besar untuk memiliki anak >2 dibandingkan dengan mereka yang tidak menggunakan. Dalam penelitian ini belum dianalisis lebih lanjut tentang pengaruh faktor yang terkait dengan penggunaan kontrasepsi, misalnya jenis kontrasepsi dan angka keberlangsungan (continuation rate) terhadap fertilitas. Data Susenas 2015 tidak menyediakan data riwayat pemakaian kontrasepsi karena survei tersebut tidak ditujukan untuk secara khusus meneliti tentang pemakaian kontrasepsi.

\section{Kesimpulan}

Sebagian besar WPK yang berstatus migran risen di Jawa Barat adalah mereka yang tergolong usia produktif dan memiliki umur reproduksi yang masih potensial. Namun, dibandingkan dengan WPK nonmigran, ternyata peluang untuk memiliki anak lebih daripada dua orang lebih kecil dibandingkan dengan WPK nonmigran. WPK migran belum terbukti meningkatkan angka fertilitas di Provinsi Jawa Barat. Wanita pernah kawin 15-49 tahun yang tinggal di wilayah perkotaan, memiliki tingkat pendidikan yang lebih rendah, dan tidak bekerja yang dapat digolongkan sebagai penduduk miskin perkotaan berpeluang memiliki anak lebih daripada dua orang.

\section{Ucapan Terima Kasih}

Terima kasih disampaikan pada pihak BKKBN Pusat dan Provinsi Jawa Barat yang telah memberikan dukungan terhadap penulisan artikel ini.

\section{Daftar Pustaka}

Alfana, Muhammad Arif Fahrudin dan Sri Rum Giyarsih. 2015. "Fertilitas dan Migrasi: Kebijakan Kependudukan Untuk Migrasi di Kabupaten Sleman". Jurnal Kajian IImu Administrasi Negara, Vol. 3 No 1.

Caldwell, J. 1982. Theory of Fertility Decline. London: Academic Press.

Davis, Kingsley and Judith Blake. 1956. "Social Structure and Fertility: An Analytic Framework". Economic Development and Cultural Change, 4(3): 211-235.

Haribaik, Maria Adelia Suryani, Ida Bagus Made Astawa, Sutarjo. 2017. "Studi Komparatif Tentang Fertilitas Antara Migran dan Non Migran di Kota Singaraja”. 
Jurnal Pendidikan Geografi. Vol. 11, No.

2. Diunduh dari https://ejournal.undiksha. ac.id/index.php/JJPG/article/view/10743 pada 30 November 2017.

Herartri, Rina; Septi Nurhayati, dan Yusna

Afrilda. 2013. Perbedaan Fertilitas Wanita

Migran dan Non Migran di Provinsi Jawa Barat. Jakarta: Puslitbang Kependudukan BKKBN Pusat.

Hervitz, Hugo M. 1985. Selectivity, Adaptation or Disruptive? A Comparison of Alternative Hypothesis of Migration on Fertility: The Case of Brazil International Migration Review.

Kulu, H. 2003. "Migration and Fertility: Competing Hypothesis Re-examined". MPIDR Working Paper, 2003-035, Rostock: Max Planck Institute for Demographic Research.

Ribe, H. \& Schultz, P. 1980. Migrant and Native Fertility at Destination Colombia: Are Migrant Selected according to their Reproductive Preferences? Unpublished monograph.

Sudibia, I Ketut, Ni Nyoman Dayuh Imbawan, AAI Marhaeni, Rusta Dewi Rustiriyuni. 2013. "Studi Komparatif Fertilitas Penduduk Antara Migran dan Non Migran di Provinsi Bali”. Piramida, Vol. 2. No IX : 77-88. 